\title{
Smallholder Livestock Commercialization
}

\section{(Komersialisasi Peternakan Skala Kecil)}

\author{
Roger Merkel \\ American Institute for Goat Research, Langston University, Langston, OK, USA \\ rcmkl@yahoo.com
}

(Diterima 23 Januari 2019 - Direvisi 28 Februari 2019 - Disetujui 4 Maret 2019)

\begin{abstract}
The world's population is expected to grow by over $30 \%$ by 2050 , putting tremendous strain on agriculture to produce the estimated additional one billion tons of cereal grains and 200 million tons of meat to feed that population. Most of the population growth will occur in Africa and Asia where the majority of smallholder farms are located. Commercialization of smallholder farms can lead to increased productivity. Producer identified constraints to commercialization include infrastructure, poor knowledge of market prices, limited access to banking services and loan opportunities, and poor extension services, among others. To overcome these constraints will take actions by various sectors. Producer must become more market oriented and take advantage of current technologies to improve production. Government organizations should develop ways to build farmer capacity in market and production activities. Research institutes and universities must conduct research to drive innovation, help farmers to apply technologies, and develop means to enhance producer knowledge. Making loans and banking services available to farmers is a main role of the private sector. The private sector can also partner with producers on marketing and market access.
\end{abstract}

Key words: Smallholder, livestock, commercialization

\begin{abstract}
ABSTRAK
Populasi dunia diperkirakan akan tumbuh lebih dari $30 \%$ pada tahun 2050, yang mana memberi tekanan besar pada bidang pertanian untuk menghasilkan tambahan sekitar satu miliar ton tanaman serealia dan 200 juta ton daging guna mencukupi kebutuhan pangan populasi tersebut. Sebagian besar pertumbuhan populasi akan terjadi di Afrika dan Asia, dimana mayoritas petani skala kecil berada. Komersialisasi peternakan skala kecil dapat membawa pada peningkatan produktivitas. Hambatan produsen dalam hal komersialisasi ini antara lain infrastruktur, kurangnya pengetahuan mengenai harga pasar, akses terbatas ke layanan perbankan dan peluang pinjaman, serta layanan penyuluhan yang kurang baik. Pangambilan tindakan di berbagai sektor diperlukan untuk mengatasi hambatan-hambatan tersebut. Produsen harus lebih berorientasi pada pasar dan memanfaatkan teknologi saat ini untuk meningkatkan produksi. Organisasi pemerintah harus mengembangkan cara untuk mengembangkan kapasitas petani dalam kegiatan pasar dan produksi. Lembaga penelitian dan universitas harus melakukan penelitian untuk mendorong inovasi, membantu petani menerapkan teknologi dan mengembangkan sarana untuk meningkatkan pengetahuan produsen. Menyediakan pinjaman dan layanan perbankan bagi para petani adalah peran utama sektor swasta. Sektor swasta juga dapat bermitra dengan produsen dalam hal pemasaran dan akses pasar.
\end{abstract}

Kata kunci: Petani kecil, peternakan, komerislaisasi

\section{INTRODUCTION}

By 2050, the world's population is expected to grow by 2.3 billion people an increase of $34 \%$, most of who will live in urban areas. This increase will place tremendous strain on agriculture and the ability of farmers to produce enough food to feed that population. FAO (2009) estimates that an additional 1 billion tons of cereal grains and 200 million tons of meat will be needed. In addition to population growth and urbanization, demand for livestock products increases as family income grows (Thornton 2010; FAO 2011).

Where will that food be produced? Lowder et al. (2016) estimate that of the world's 570 million farms, over 475 million, or $84 \%$, are smaller than two hectares. The authors further state that small farms are more prevalent in countries with lower levels of income and account for about 70 to $80 \%$ of farms and $12 \%$ of farmland in East Asia and the Pacific (excluding China), South Asia, and sub-Saharan Africa. When looking at projections of population growth, the regions of Africa and Asia, where small farms predominate, will grow the most. Over one-half of the world's expected increase in population by 2050 will occur in Africa (1.6 billion people), followed by Asia (750 million people) (United Nations 2017).

To feed a rapidly growing population will require increased productivity and efficiency throughout the 
agricultural sector, most importantly for the large number of small farms found in these regions. Satisfying the increased demand for meat and meat products will require higher production per animal with farmers producing what the market demands (Henriksen \& Rota 2014). Whereas cattle are the predominant ruminant animal in much of the world, the importance of small ruminants in livestock production systems where much of the future population growth will occur, cannot be overlooked. Excluding China, over $79 \%$ of the world's goats and almost $60 \%$ of the world's sheep are found in Africa and Asia compared to $48 \%$ of the world's cattle and only $16 \%$ of the world's pigs (FAO 2011).

\section{WHAT IS CONSIDERED COMMERCIALIZATION?}

There are various definitions of commercialization in regards to small farm production. Commercialization can be looked at in terms of marketed output or purchased inputs on an output basis (Jaleta et al. 2009). Another definition of commercialization is that household decisions on product choice and input use are made based on the principles of profit maximization (Pingali 1997). Still another definition is the deliberate action on the part of the agricultural producers of their own free will or by means of coercion to use land, labor, implements and other inputs so that a greater or smaller part of the crops and/or animals produced is for exchange or sale (Okezie et al. 2008).

Berhanu \& Moti (2010) discuss commercialization in terms of market orientation and market participation. Market orientation is production for profit maximization whereas market participation is simply the products offered for sale. Commercialization is the combination of the two, where market oriented production impacts market participation by the actual amount and type of product sold.

Commercialization, then, begins with a conscious decision by a producer to target and enter a specific market. The basic difference between subsistence and commercial production is that subsistence farmers sell only whatever surplus is available after home consumption needs have been met whereas commercial farm production is based on market signals, projections of cost and profit, and comparative advantages of an individual producer (Jaleta et al. 2009).

\section{What is the benefit of smallholder commercialization?}

Through increased and more efficient production through commercialization, smallholder producers can increase income and reduce poverty in rural areas. Food security, nutrition, health, education, and other areas will also improve. This is particularly true for women farmers as women have been shown to utilize more of their income to meet household needs than do men (World Bank 2009).

Henriksen \& Rota (2014) state that the smallholder sector of livestock production should be targeted for commercialization. Reasons for this include: the fact that a large proportion of the population in many countries is involved in smallholder agriculture means that this sector already produces a major share of the country's food; large scale livestock farming systems often do not have greater production efficiencies as compared to smallholder production; current inefficient production practices encroach on natural forests, rangelands, etc., and enhanced efficiency by current smallholder producers can help preserve these resources; the smallholder production system has the greatest potential for increased productivity; many smallholders are already initiating this transformation; and investment in higher productivity from smallholder farming communities positively impacts rural emplyment and economic growth.

The smallholder sector also has great potential for improvement in production efficiency. Boka (2017) reports that the majority of Kenyan rural households depending on agriculture are smallholder farmers. These households account for $75 \%$ of agricultural output and $70 \%$ of marketed agricultural produce; however, only $20 \%$ of these households account for over two-thirds of marketed products, illustrating the low current output of most farms. Enhancing livestock nutrition (such as through supplementation using tree legumes like Sesbania (Dahlanuddin et al. 2016), Leucaena (Soares et al. 2018), or Indigofera (Ginting et al. 2010; Tarigan et al. 2018), genetics (such as crossbreeding with dairy breeds to improve milk production (Galukande et al. 2013), health (enhancing calf survivability through supplementation strategies (Jelantik et al. 2008), and management (such as using body condition score as a management tool to enhance calf growth and reduce mortality (Dahlanuddin et al. 2016) are examples of technologies that can immediately impact livestock production (Dilger et al. 2016). Further, more advanced technologies are available and more are being developed that could be of use, e.g., genomics (Thornton 2010). As an example, genomic testing of dairy bulls has been accepted as an indicator of his eventual evaluation based upon production by progeny. This leads to better sire selection and increases rate of genetic progress (Wiggins et al. 2017).

Throughout the world, people have been leaving rural areas and moving to urban centers for employment, educational opportunities, and other 
reasons (FAO 2017). In many countries, farm size has dwindled forcing people to search for livelihoods elsewhere. Large numbers of people leaving rural areas impacts not only rural economy but also the social fabric of rural areas. Investing and promoting smallholder commercialization of livestock production and building associated processing and marketing facilities can have a very beneficial impact on rural economic growth. Thus, another benefit to commercialization is that more money can remain in rural areas stimulating not only agriculture but also other businesses. This job growth can lead to off-farm employment opportunities for young men and women of farming families who might otherwise leave these family farms in rural communities in search of work. Keeping these young people in rural communities allows for a greater chance of continuity in maintaining family farms.

\section{CONSTRAINTS TO COMMERCIALIZATION}

Farmers around the world face many constraints that limit their ability to commercialize production. Constraints reported by various authors studying conditions in several different countries in vastly different production and climatic environments share many of the same issues. Much of the literature on smallholder commercialization focuses on crops. For this paper, results from studies focusing on livestock in Indonesia (Budisatria 2006), United States (Gilipsie et al. 2013) South Africa (Khapayi \& Celliers 2016), Ethiopia (Boka 2017), the Gambia (Sanyang et al. 2017), and Kenya (Bonilla et al. 2018) have been compiled. In most reports, a major constraint was infrastructure; poor roads that limit transportation to local markets and to distant markets near large urban centers where animal prices may be higher. A lack of transportation from rural areas has led to inadequate market access.

Many producers decry the lack of market information and knowledge of sale prices at distant markets. High market transaction costs decrease profit and can lead to exploitation of smallholder producers. At local markets, animals may be purchased on a per head basis instead of live weight. This coupled with the lack of a grading system to provide a price differential amongst animals of differing quality leads to producers not being adequately compensated for animals with superior meat conformation.

Whilst many rural areas have small abattoirs processing livestock for local consumption, large processing facilities are often lacking. Farmers selling to those markets often must deal with middlemen who purchase animals for further resale. Farmers selling directly to distant processing facilities likely receive a lower price as animals lose weight during transportation. Regarding goat slaughter in the US, there are few large processing facilities near states with large goat numbers, i.e., Texas, Tennessee, Missouri, Oklahoma. Roughly one in four goats slaughtered in the US is processed in the state of New Jersey, necessitating extensive trucking (USDA NASS 2018).

Livestock producers have little to no control of the market value chain for livestock products. Larger profits usually occur near the end of the market value chain where final products are sold to consumers. Producers, however, usually have very little involvement in that step and can miss out on profit. Producers also list little government support as a constraint for expansion or commercialization. This includes inadequate extension services, particularly programs and information expressly designed for women farmers, and a lack of relevant research.

Producers can be hampered in their quest for commercialization by limited access to banking services and financing, particularly in terms of land or facility expansion. Agricultural technologies that could increase production, e.g., artificial insemination, or improve health, e.g., vaccination programs, may be non-existent or cost prohibitive for very small-scale producers.

Producers list high feed costs, animal diseases, and lack of veterinary services, internal parasites, drought, inadequate fodder, and pasture availability as constraints. Some producers recognize a need to enhance marketing skills and ability to use and interpret market data. A lack of knowledge on how to improve farm production is another area producers label as a constraint and underscores a lack of adequate livestock extension services. The study by Khapayi \& Celliers (2016) in Eastern Cape Province of South Africa reported that 48, 94, 74, 96, and $30 \%$ of respondents having beef cattle said they had inadequate knowledge of or did not know skills relating to animal health, animal hygiene, animal breeding, artificial insemination, and animal nutrition, respectively.

\section{ROLES OF DIFFERENT SECTORS IN SMALLHOLDER COMMERCIALIZATION}

\section{Producers}

The first thing a producer must do to become commercialized is make the decision to enter a specific market with the aim of maximizing profit, not just selling surplus production. As Budisatria (2006) stated regarding small ruminant production in Central Java, Indonesia, "Firstly, we have to change farmers' opinion regarding small ruminant functions. As long as farmers are of the opinion that small ruminants cannot be used as an important source of income, they will always regard small ruminants as a secondary activity." 
Once the decision has been made to become market oriented, a producer must look at his operation and see what changes need to be made to become competitive and what barriers and challenges must be overcome. Available technologies that can enhance production must be explored and feasibility of adoption considered. Many technologies are low-cost and are easily implemented and some examples are given below. Other technologies may be more costly to implement, such as expanding facilities or undertaking genetic improvement, for example, and a producer may need training or financial assistance in order to take advantage of them. Other barriers may be out of a producer's control such as infrastructure, market access, development of genetic indices or genomics, etc., as outlined previously.

Production technologies that can easily be implemented deal with type of animals raised, management, health, nutrition, and selection. Often, one of the first changes a producer can implement is the type of animal kept on the farm. In a subsistence situation, livestock may be kept for long periods of time as their function is not profit but as an asset readily convertible into cash when needs arise. However, increasing the turnover rate of livestock will take advantage of an animal's inherent production and growth pattern. A young meat animal is more efficient at using consumed nutrients for tissue accretion than an older animal that is no longer growing. Metabolizable energy for maintenance has been shown to increase with age in Boer goats (Tovar-Luna, et al. 2017). Thus, the conversion ratio of feed consumed to product is better in young versus older animals. For a farmer to make most efficient use of available nutrients, he or she must sell animals at an optimum weight and age rather than feeding them past the time when they should be sold. The goal should be to increase efficiency of production per animal.

Targeted feeding of specific groups of animals can enhance nutrition. Young, growing animals have different nutritional needs than do pregnant animals. Selection of feedstuffs can be improved, even small changes such as selecting forages with higher leaf:stem ratios can improve the amount of available nutrients. Urea treatment of crop residues can improve quality of straw through increasing nitrogen content, reducing neutral detergent fiber content, and increasing digestibility (Abebe et al. 2004). Management techniques can prevent disease entry into the herd (biosecurity) through getting the health history of purchased animals and use of a quarantine period. Having a sick pen for ill animals can prevent disease spread (biocontainment). Selective culling can rid the herd of diseased or carrier animals. For blood-sucking internal parasites, such as Haemonchus contortus, using the FAMACHA ${ }^{\odot}$ system of checking color of mucous membranes can detect help chronically anemic animals that do not respond to treatment. Ridding the herd of these animals can reduce parasites deposited on pasture. Record keeping is essential for all types of production, especially commercial production. Records assist in selection of the best animals for replacements and are needed for economic analysis of the farm operation.

Farmers will need access to or assistance with some performance enhancing technologies. Artificial insemination, for example, requires specialized equipment, resources, and training. Vaccines may be available through the private sector or a government sponsored program. Feed supplements and additives to increase efficiency are items purchased through the private sector.

\section{Government}

The role of government in supporting smallholder commercialization goes beyond simple infrastructure enhancements. Henriksen \& Rota (2014) outline several areas where government support is essential to improve the prospect of smallholder commercialization. These include support in developing farmer organizations for collective actions, such as input purchase and marketing endeavors, building farmer capacity through training programs for future farmers, providing technical services based upon need to smallholder communities, and regulatory frameworks for inputs and marketing of output, among others. Getting farmers involved in all aspects of the market chain or support to establish marketing structures allows farmers to achieve higher economic benefit from livestock products. Training in value addition to livestock products or direct marketing are other avenues whereby government support can lead to increased producer opportunities.

Enhancing farmer knowledge is imperative in improving production and supporting commercialization. Complaints regarding livestock extension services include infrequent visits, programs that do not fit the production conditions, as well as a lack of attention to female producers and few female extension agents that limits presentation and adoption of technology by female farmers (Budisatria 2006; Juma 2015). Government extension services should take steps to ameliorate these issues, particularly in the case of women producers. Whereas roughly $50 \%$ of farmers in sub-Saharan Africa are women, only 69\% receive visits from extension personnel compared to $97 \%$ of men. Furthermore, only $7 \%$ of extension agents are female (Juma 2015). The importance of female extension agents working with women is underscored by a study in Nigeria that found women farmers served by female extension agents had higher participation in 
extension services, greater knowledge gained, and higher adoption of recommended practices than did women served by male extension personnel (Lahai et al. 1999).

Governments can also work with donor agencies to conduct programs aimed at developing the livestock sector of the economy. These programs can be aimed at production, marketing, value chain, or other areas. An example of a production-oriented project is the Ethiopian Sheep and Goat Productivity Program supported by the USAID Mission in Addis Ababa, Ethiopia and conducted by US universities of which Langston University provided the technical support. Improved genetics, appropriate on-farm technologies, training of village development agents, and herd health were the four foci of this project. Providing marketing information via cell phones has been the focus of USAID-funded projects in Mali and East Africa.

\section{Research institutes and universities}

National research institutes and universities play a role in ameliorating production constraints, developing technologies, and impacting national policies. In the US, the land-grant university system has a tripartite mission of teaching, research, and extension. Faculty often have split appointments among the three areas and interact with students, producers, and other research scientists. This interaction help faculty recognize and solve problems identified by producers, develop producer-friendly materials for use by extension personnel, and train students in relevant material. In essence, there is a feedback circle whereby each area touches and impacts the other. National research institutes, whose focus is on research, lack students and may not be directly involved with extension (Juma 2015).

The disconnect of research, extension, and teaching can lead to the wrong issues being studied, inadequate preparation of students, and development of extension programs not relevant to current constraints faced by farmers as stated by Budisatria (2006). Government support mechanisms, such as forums or formal collaborative agreements amongst institutions for partnering and collaboration, can help alleviate these concerns. Further, the agriculture industry is increasingly using advanced technology in everyday production, examples being wireless fencing, rumination sensors to detect illness and estrus, and drones to detect forage availability, among others. Thus, computer programmers, electrical engineers, mechanical engineers, biotechnologists, and scientists in other fields are becoming as important in agricultural research and development as is a basic animal scientist. Both universities and research institutes must have personnel or mechanisms in place to take advantage of these disparate fields to drive innovation that can positively impact smallholder production.

Research institutes and universities do have a role to play in using current technology. In the area of breeding and genetics research institutes and universities can be the organization calculating selection indices such as expected breeding value (EBV), expected progeny difference (EPG), 305-day lactation amounts, and others that could be used by producers for genetic improvement. On-farm record keeping and performance evaluation are essential to derive data that can be statistically evaluated and modeled. Scientists can work with extension agencies and farmers to create the needed data collection framework to utilize these technologies such as is done by collaboration and work of agriculture research and extension organizations in Indonesia. While this is an advanced step for many countries, farmers should be urged to participate and utilize such indices and technologies where they exist and work to further develop them.

The future use of genomic selection to identify genetically superior animals for breeding purposes has potential to revolutionize the livestock industry (Goddard \& Hayes 2007; Goddard 2009). Genomics allows animal selection from genetic marker information so that selection can be done more accurately and at an earlier age than when using many traditional indices. Much research work must be done to establish reference populations, record and analyze data, and develop appropriate technology for farm use. Much work has been done on various livestock species that can be utilized. An example of a genetic marker used in dairy goats is for alpha s1 casein, an indicator of cheese production. In the US, producers can have animals tested for this protein by the University of California-Davis, California, USA.

In the area of extension, universities can be very valuable in developing training materials and methods to work with farmers. Traditional avenues such as fact sheets and booklets have been augmented with webbased materials and social media posts. The importance of electronic media and materials will grow in the future as producers seek out information. Osti et al. (2016) found that 58\% of US goat producers searched for market information on the internet. Kirui \& Njiraini (2013) found that farmer collectives and use of cell phones for information gathering was positively associated with increased farmer commercialization, particularly among women.

As more and more producers use cell phones and other web-enabled devices, they will turn to the internet for a source of production information. Research institutes and universities play an important role in providing correct, scientific-based production information on electronic media. The American 
Institute for Goat Research of Langston University has created on-line training and certification programs for meat goat and dairy goat producers. Producers enroll and access training modules on all aspects of production after which they are tested to determine knowledge gained. Upon completion of required modules and a certain number of elective modules, the producer can receive a certificate stating that he or she is a quality producer. The programs are self-paced and available to anyone with an internet connection. Indeed, the first person to complete the dairy goat certification program was from Zimbabwe and over 15 countries are represented among certified meat and dairy goat producers.

Developing innovative delivery methods for producer training is another role well suited to universities with an extension mandate. There will always be a need for face-to-face interactions with producers but other means of providing training can be used for most materials. A case in point is how to provide internet-based training programs, like that described for goat producers, to persons with no internet connection? Even in the US, one in five people in rural areas do not access the internet for a variety of reasons (Anderson et al. 2018). One way to solve that constraint is to take the web-based training to those producers by adapting already developed technology. The Raspberry Pi is a small computer that can be held in one's hand. While small, the Raspberry Pi has capability to create a small wireless network. Training materials can be placed on the $\mathrm{Pi}$ in a web-based format. Anyone with a cell phone could access the materials or inexpensive tablets can be provided to participants without a cell phone. A farmer group could use the Raspberry Pi training arrangement. Once completed, the Raspberry Pi can be used elsewhere or the content changed for additional training. Even college course materials could be loaded onto the device and distance learning can be accomplished. Designing and utilizing technologies like these in conjunction with traditional extension services can provide needed information to producers helping their farm become more efficient.

\section{Private sector}

The private sector will respond to needs and demands of the marketplace through provision of production inputs, eg., feedstuffs, health supplies, farm supplies, etc. Banking services and access to loan funding, particularly microloans, can help producers obtain needed inputs. The private sector will also commercialize research findings and developed technologies, such as the genomic selection outlined above. There are many companies already offering such services for many livestock species. Price and appropriateness of such testing will be an issue with smallholder production.

The private sector has partnered with government, donor agencies and other NGOs to provide services to farmers. Push notifications on market information have been discussed above. Another innovative project is iCow, a program whereby farmers can subscribe to recieve SMS messages on dairy cattle production. Producers can access the iCow farmer library through their smart phones to look for information on other livestock and poultry species as well as crops.

As smallholder farmers commercialize, they have great opportunity to engage with the private sector. This could be in the form of contractual agreements or contract growing to provide livestock. Increasingly, consumers wish to know more about the food they consume. This has been seen in many developed countries where issues of animal welfare, production conditions, feeding of genetically modified crops, and use of medications, among other issues, impact what consumers choose to buy. Some US producers obtain certifications relating to production conditions and animal welfare to use as marketing tools in promoting their products. In the arena of farm animal welfare, certifications found in the US include Animal Welfare Approved by A Greener World, Certified Humane by Humane Farm Animal Care, and American Humane Certified by the American Humane Association. Certifications based upon diet include Certified Grassfed by the American Grassfed Association. Certified organic production is a production system requiring government certification, standards of which will vary by country.

Producer groups have potential to use such certifications to advertise and produce specific types of livestock for consumer groups. These may be specific livestock for holiday markets or specific types of livestock for upscale restaurants. Producer groups can even "brand" their product in the marketplace. Such products have been introduced in the US and other markets, either sold directly or on-line, one example being "Certified Organic Grassfed Goat" (Windy N Ranch 2018).

Another way that producers can attract investment is through the selling of "shares" in their livestock. Consumers purchase shares of livestock on a farm or from a farmer group. This entitles the shareholder to gain benefit from these products. This has mainly been done with dairy animals such as goats (A Better Way Farms 2018) and cows, so that shareholders can obtain raw, unpasteurized milk that is illegal to sell in the US but that an "owner" of the animal can consume. Potential may exist to expand a share program into meat producing animals, particularly if a certain breed, production system, or production area could be advertised. Whereas many of these ideas may seem far- 
fetched in today's environment, the ubiquitous presence of cell phones and network access mean that it is only a matter of time before enterprising agriculture producers begin to utilize these marketing methods as a means of increasing income.

\section{CONCLUSION}

As the world demand for meat and meat products grows, increased production and efficiency will be demanded from all sectors of the livestock industry. Smallholder livestock producers dominate in many of the world's regions where future increases in population will necessitate large increases in agricultural production. These smallholder producers have great potential to increase production and help fulfill that demand. Smallholder defined constraints to increased production and commercialization range from a lack of physical infrastructure linking them to markets to lack of extension services providing needed production information. Concerted efforts will be needed by government, universities, research centers, extension services, and producers themselves to overcome constraints. Benefits of commercialization will accrue to all sectors of the livestock industry and general population.

\section{REFERENCES}

A Better Way Farms. 2018. Goat herdshare program. Get raw goat's milk straight from the farm. A Better Way Farms [Internet]. Available from: http://www.abetterwayfarms.com/rawmilk.html

Abebe G, Merkel RC, Animut G, Sahlu T, Goetsch AL. 2004. Effects of ammoniation of wheat straw and supplementation with soybean meal or broiler litter on feed intake and digestion in yearling Spanish goat wethers. Small Rum Res. 51:37-46.

Anderson M, Perrin A, Jiang J. 2018. 11\% of Americans don't use the internet. Who are they? Pew Research Center [Internet]. Available from: http://www. pewresearch.org/fact-tank/2018/03/05/someamericans-dont-use-the-internet-who-are-they/

Berhanu G, Moti J. 2010. Commercialization of smallholders: Does market orientation translate into market participation? In: Improving Productivity and Market Success. (IPMS) of Ethiopian Farmers Project Working Paper 22. Nairobi (Kenya): ILRI.

Boka GT. 2017. Climate change challenges, smallholders' commercialization, and progress out of poverty in Ethiopia. In: Shimeles A, Anyanwu JC, Faye I, Ngaruko F, Simpasa A, Salami AO, VerdierChouchane A, editors. Working Paper Series No. 253, African Development Bank. Abidjan (Côte d'Ivoire): African Development Bank.
Bonilla J, McCarthy N, Mugatha S, Rai N, Coombes A, Brubaker J. 2018. Impact evaluation of the smallholder dairy commercialization programme in Kenya. In: 3ie Impact Eval Rep 73 [Internet]. New Delhi (India): International Initiative for Impact Evaluation (3ie). Available from: https://doi.org/ 10.23846/tw4IE73.

Budisatria IGS. 2006. Dynamics of small ruminant development in Central Java-Indonesia [PhD Thesis]. [Wageningen, (Netherlands)]: Wageningen University.

Dahlanuddin D, Supriyadi M, Panjaitan TS, Poppi DP, Quigley SP. 2016. Increased body condition during lactation increases milk production and pre-weaning growth of Bali cattle. J Anim Sci. 94:399-400.

Dilger AC, Schroeder AL, Moseley WM. 2016. Barriers to global implementation of current and development of new performance-enhancing technologies in meat production. Anim Front. 6:50-55.

FAO. 2009. Global agriculture towards 2050. High level expert forum - How to feed the world in 2050 [Internet]. Rome (Italy): Food and Agricultural Organization. Available from: http://www.fao.org/ fileadmin/templates/wsfs/docs/Issues_papers/HLEF2 050_Global_Agriculture.pdf

FAO. 2011. World livestock 2011 - Livestock in food security. Rome (Italy): Food and Agricultural Organization.

FAO. 2017. The state of food and agriculture [Internet]. Rome (Italy): Food and Agricultural Organization. Available from: http://www.fao.org/3/a-I7658E.pdf.

Gilipsie J, Nyaupane N, McMillin K. 2013. Producer perceptions of important challenges currently facing the United States meat-goat industry. Prof Anim Sci. 29:333-344.

Goddard M. 2009. Genomic selection: Prediction of accuracy and maximisation of long term response. Genetica. 136:245-257.

Goddard ME, Hayes BJ. 2007. Genomic selection. J Anim Breed Genet. 124:323-330.

Henriksen J, Rota A. 2014. Commercialization of livestock production; towards a profitable and market-oriented smallholder livestock production system. Livest Res Rural Dev [Internet]. 26. Available from: http://www.lrrd.org/lrrd26/5/hend26090.html

Jaleta M, Gebremedhin B, Hoekstra D. 2009. Smallholder commercialization: Processes, determinants and impact. In: Discussion Paper No. 18. Improving Productivity and Market Success (IPMS) of Ethiopian Farmers Project. Nairobi (Kenya): ILRI.

Juma C. 2015. The new harvest: Agricultural innovation in Africa [Internet]. 2nd ed. New York (US): Oxford University Press. Available from: https://www.belfercenter.org/sites/default/files/files/p ublication/TNH-final-Juma2.pdf 
Khapayi M, Celliers PR. 2016. Factors limiting and preventing emerging farmers to progress to commercial agricultural farming in the king william's town area of the Eastern Cape Province, South Africa. South African Soc Agric Ext [Internet]. 44:25-41. Available from: http://dx.doi.org/10.17159/24133221/2016/v44n1a374

Kirui OK, Njiraini GW. 2013. Determinants of agricultural commercialization among the rural poor: Role of ICT and Collective action initiatives and gender perspective in Kenya. In: AAAE Fourth Int Conf [Internet]. 22-25 September 2013, Hammamet (Tunisia): African Association of Agricultural Economists. Available from: https://ideas.repec.org/ p/ags/aaae13/161618.html

Lahai BAN, Goldey P, Jones GE. 1999. The gender of the extension agent and farmers' access to and participation in agricultural extension in Nigeria. $\mathrm{J}$ Agric Educ Ext. 6:223-233.

Lowder SK, Skoet J, Raney T. 2016. The number, size, and distribution of farms, smallholder farms, and family farms worldwide. World Dev. 87:16-29.

Okezie CA, Nwosu AC, Okezie CR. 2008. An assessment of the extent of the commercialization of agriculture in Abia State, Nigeria. Agric J. 3:129-133.

Osti S, Gillespie J, Nyaupane N, McMillin K. 2016. Meat goat production in the United States: Adoption of technologies, management practices, and production systems. J ASFMRA. 2016:116-129.
Pingali PL. 1997. From subsistence to commercial production systems: The transformation of Asian agriculture. Am J Agric Econ. 79:628-634.

Sanyang SE, Jobe L, Drammeh M. 2017. Commercialization of livestock through value chain approach by smallholder farmers in the Gambia. World J Agric Sci. 13:172-178

Thornton PK. 2010. Livestock production: Recent trends, future prospects. Philos Trans R Soc B Biol Sci. 365:2853-2867.

Tovar-Luna, I, Puchala R, Sahlu T, Goetsch AL. 2017. Effects of gender and age on energy use by young Boer goats. Livest Sci. 199:86-94.

United Nations. 2017. World population prospects: The 2017 revision, key findings and advance tables. Working Paper No. ESA/P/WP/248. New York (US): United Nations, Department of Economic and Social Affairs, Population Division.

USDA NASS. 2018. Farms and land in farms 2017 summary. Itacha (US): United States Department of Agriculture. Available from: http://usda.mannlib.cornell.edu/usda/ current/FarmLandIn/FarmLandIn-02-16-2018.pdf

Wiggins GR, Cole JB, Hubbard SM, Sonstegard TS. 2017. Genomic selection in dairy cattle: The USDA experience. Ann Rev Anim Biosec. 5:309-327.

Windy N Ranch. 2018. Certified organic pastured goat. Wind $\mathrm{N}$ Ranch [Internet]. Available from: https://www.windynranch.com/grass-fed-goat

World Bank. 2009. Gender in agriculture sourcebook. Washington DC (US): The World Bank. 